\title{
Seminar on Inter-University Co-operation in West Africa
}

AN International Seminar, sponsored by the University College of Sierra Leone, Fourah Bay College, and the Congress for Cultural Freedom (Congrès pour la Liberté de la Culture), held at Fourah Bay College from in to i 6 December, was attended by representatives of universities in West Africa, France, the United Kingdom, and U.S.A., ministries of education, Unesco, the Carnegie Corporation, the Rockefeller Foundation, and the United Kingdom Department of Technical Co-operation. Among the subjects discussed were: the functions of West African universities in the field of higher education, on which papers were presented by Sir Eric Ashby and Dr. K. A. Busia; a plan for the organization of West African interuniversity co-operation, by Mr. C. W. L. Beavan; the need for a West African intellectual community and the role of inter-African University co-operation in its formation, by Dr. Davidson Nicol and Professor Edward Shils; problems of co-operation between the Englishand French-speaking universities of West Africa, by M. Denis Lévy and M. G. Capelle; co-operation between universities in printing and publishing and the creation of a clearinghouse and bibliographical services on West African subjects, by Mr. John Harris and Professor Arthur Porter; extra-mural activities, by Dr. Victor King; and co-operation in methods of recruitment and planning for common standards and exchange of personnel, by Mr. I. C. M. Maxwell and Mr. M. Dowuona. The Seminar recommended the establishment of an association of West African universities and an exchange of teachers and research staff. The study of a second language of international communication in use in West Africaeither English or French as appropriate-was also recommended. The question of the place of African studies in university curricula should be considered by a specially convened conference of representatives of universities in Tropical Africa.

Further information about the Seminar, whose papers and resolutions are to be published in due course, may be obtained from: Congrès pour la Liberté de la Culture, ro4 Boulevard Haussmann, Paris $8 \mathrm{e}$.

\section{International Directory of African Studies (Including Madagascar)}

The pre-issue (No. o) of this Directory, prepared under the auspices of Unesco, is to be published in I962. One copy will be sent free of charge to every University or Institute interested in African Studies asking for it. Please order your copy at once from: International Directory of African Studies, c/o International Council for Philosophy and Humanistic Studies, Maison de l'Unesco, 6 rue Franklin, Paris r6e.

\section{Répertoire International des Renseignements et des Recherches Africanistes et Malgaches}

LE numéro préparatoire (No o) de ce Répertoire, dû à l'initiative de l'Unesco, paraîtra en r962. Un exemplaire en sera envoyé gratuitement à toute Université ou Institution s'intéressant aux études africanistes qui en fera la demande. Commandez immédiatement votre exemplaire a: Repertoire international africaniste, $c / 0$ Conseil international de la philosophie et des sciences humaines, Maison de l'Unesco, 6 rue Franklin, Paris 16 e.

\section{'The Migrant Cocoa Farmers of Southern Ghana': A Correction}

The author of 'The Migrant Cocoa Farmers in Southern Ghana' (Africa, July I96r, pp. $209-30$ ) asks us to point out that on page $2 \mathrm{I}_{3}$, line 5 , the scale should be 40 inches to a mile, not 8 inches. 